\title{
CANADA'S NEXT STEP IN TOBACCO CONTROL LAWS: is Plain Packaging Legislation a Viable Proposal?
}

\author{
MARIETTE BRENNAN*
}

It is widely accepted that tobacco consumption has a number of dangerous side effects. While the federal and provincial governments have introduced a number of laws in order to decrease the number of smokers in Canada, no law on the plain packaging of tobacco products has been introduced. This article explains what plain packaging is, and then goes on to analyze whether a plain packaging law would violate Canada's constitutional laws from both a division of powers and a Canadian Charter of Rights and Freedoms perspective.
Il est largement admis que le tabagisme produit un certain nombre d'effets secondaires dangereux. Bien que les gouvernements fédéral et provinciaux aient adopté plusieurs lois dans le but de réduire le nombre de fumeurs au Canada, aucune loi n'a été adoptée sur la banalisation des emballages de produits du tabac. L'auteur explique en quoi consiste la banalisation des emballages, puis analyse si une telle loi enfreindrait les lois constitutionnelles du Canada sur le plan de la division des pouvoirs et de la Charte canadienne des droits et libertés.

\section{TABLE OF CONTENTS}

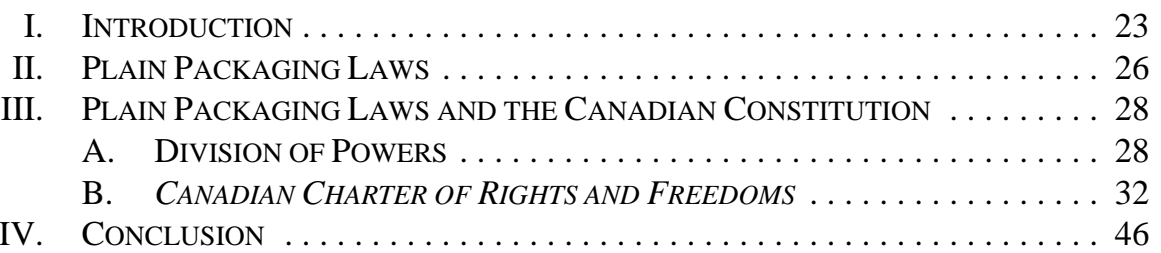

\section{INTRODUCTION}

It is common knowledge that tobacco consumption has dangerous side effects; for years medical experts have linked tobacco use to various deadly medical illnesses. ${ }^{1}$ Despite knowing these medical risks, tobacco companies continue to produce cigarettes, and people continue to smoke. Faced with a public health crisis that will, this year, cost over \$17 billion and cause over 37,000 Canadians to die prematurely, the federal and provincial governments heavily regulate the sale of tobacco products within their jurisdictions. ${ }^{2}$

PhD (Osgoode Hall), assistant professor at Lakehead University’s Faculty of Law. The author would like to thank Bond University for its assistance in the preparation of this article. She would also like to thank the external reviewers for their comments and suggestions.

1 For instance, medical evidence has proven that smoking can lead to the following cancers: cancer of the cervix, oesophagus, kidney, bladder, larynx, lung, pancreas, stomach, and pharynx (Centers for Disease Control and Prevention, "Health Effects of Cigarette Smoking,” online: Centers for Disease Control and Prevention <http://www.cdc.gov/tobacco/data_statistics/fact_sheets/health_effects/effects_cig_smoking /index.htm>). In addition to these cancer risks, smoking has also been found to cause ischemic heart disease, lung disease (including emphysema), strokes, and pneumonia (see Medline Plus, "Risks of Tobacco,” online: US National Library of Medicine (National Institutes of Health) <http://www.nlm.nih. gov/medlineplus/ency/article/002032.htm>).

2 Note that both the federal and provincial governments have the ability to pass laws relating to tobacco consumption; the federal government typically does so using its constitutionally assigned power over criminal law, and the provincial governments do so using their power over health. The provincial governments have been responsible for some significant advances in anti-tobacco legislation (see e.g. British Columbia v Imperial Tobacco Canada Ltd, 2005 SCC 49, [2005] 2 SCR 473). In this case, the British Columbia legislature passed a law that allowed the province to sue tobacco companies to recover health care costs for patients that were ill with tobacco related diseases. The Supreme Court of Canada upheld the legislation. This case resulted in other provinces passing similar legislation (see e.g. Ontario's Tobacco Damages and Health Care Costs Recovery Act, 2009, SO 2009, c 13; Newfoundland's 
For close to 50 years, the federal and provincial governments have tried a myriad of techniques to eradicate tobacco consumption among the general population. For instance, they have restricted tobacco advertisement, ${ }^{3}$ adopted strict guidelines for the labelling of cigarette packages, ${ }^{4}$ implemented laws that restrict the sale of cigarettes to minors, ${ }^{5}$ heavily taxed cigarettes, ${ }^{6}$ and, for the most part, required public places to be smoke free. ${ }^{7}$ Since these laws have passed, the number of Canadian smokers has decreased. ${ }^{8}$ However, recently, these methods have become less successful. ${ }^{9}$ The percentage of smokers in the Canadian population changed minimally between 2009 and 2010. This fact, coupled with a continual slow-down of the overall decrease in the population of Canadian smokers, has experts concerned that the current government anti-smoking campaigns are inadequate. ${ }^{10}$

Lately there has been a call for more radical laws to decrease tobacco consumption in the Canadian population. In the fall of 2011, the federal government proposed a new law on the labelling of tobacco packaging. This law sought to increase the warning labels on cigarette packages from 50 percent of the package to 75 percent of the package. ${ }^{11}$ The Australian

Tobacco Health Care Costs Recovery Act, SNL 2001, c T-4.2; Saskatchewan's The Tobacco Damages and Health Care Costs Recovery Act, SS 2007, c T-14.2; New Brunswick's Tobacco Damages and Health Care Costs Recovery Act, SNB 2006, c T-7.5). See also, Rothmans, Benson \& Hedges Inc v Saskatchewan, 2005 SCC 13, [2005] 1 SCR 188. In this case, the Supreme Court of Canada upheld provincial legislation on tobacco advertising. Both the federal government and the Saskatchewan provincial government had enacted legislation banning certain types of tobacco advertising; the provincial legislation included restrictions that were more severe than the federal government. The Court concluded that both pieces of legislation were validly enacted and both could remain in operation. While it remains a possibility that an individual province may choose to enact plain packaging legislation within its respective jurisdiction, this article will only be focusing on the potential constitutional arguments of federally enacted plain packaging legislation. See also, Health Canada, "Health Concerns: Overview of Health Risks of Smoking," online: Health Canada <http://www.hcsc.gc.ca/hc-ps/tobactabac.res/news-nouvelles/risks-risques-eng.php>; JL Reid et al, Tobacco Use in Canada: Patterns and Trends, 2013 Edition (Waterloo: Propel Centre for Population Health Impact, 2013) at 1.

See Tobacco Act, SC, 1997, c 13, s 22 [Tobacco Act Canada]. See also David Sweanor, “A Canadian’s Perspective: Limits of Tobacco Regulation” (2008) 34:4 Wm Mitchell L Rev 1595 at 1596.

$4 \quad$ Tobacco Act, ibid, Part III. See also Sweanor, ibid at 1596.

5 See for instance Tobacco Act, ibid, Part II; see also, Smoke-Free Ontario Act, SO 1994, c 10; Tobacco Sales Act, SNB 1993, c T-6.1; Tobacco Act, RSQ 1998, c T-0.01 [Tobacco Act QC]; Tobacco Control Act, SNL 1993, c T-41 [Tobacco Control Act NL]; Tobacco Reduction Act, SA 2005, c T-3.8; Tobacco Control Act, RSBC 1996, c 451 [Tobacco Control Act BC].

6 In Canada, taxes on tobacco products are among the highest in the world. Furthermore, these taxes have been levied for the specific intention of reducing tobacco consumption. See David Sweanor \& Ken Kyle, "Legislation and Applied Economics in the Pursuit of Public Health: Canada,” in Joy de Beyer \& Linda Waverly Brigden, eds, Tobacco Control Policy: Strategies, Successes, and Setbacks (Washington, DC: World Bank, 2003) 71 at 87-90. See also Sweanor, supra note 3 at 1596.

7 Please note that both the federal and provincial governments pass tobacco control legislation. The provincial governments have passed tobacco control laws that fall within their areas of jurisdiction. See Non-Smokers' Health Act, RSC 1985, c 15; Tobacco Act Canada, supra note 3; Smoke-Free Ontario Act, SO 1994, c 10; Tobacco Sales Act, supra note 5; Tobacco Act QC, supra note 5; Tobacco Control Act NL, supra note 5; Tobacco Reduction Act, supra note 5; Tobacco Control Act BC, supra note 5. In 1999, approximately 25.2 percent of the Canadian population were classified as smokers (approximately 21 percent of the population were daily smokers and 4.2 percent were non-daily smokers) (Reid et al, supra note 2 at 15). By 2010, the most recent statistics available, the number of Canadian smokers was 16.7 percent (approximately 13.1 percent of the population were daily smokers and 3.6 percent were considered non-daily smokers) (ibid).

Ibid at 1 .

Ibid at $1,15$.

See Tobacco Products Labelling Regulations (Cigarettes and Little Cigars), SOR/2011-177. See also Leah McDaniel, “Tobacco Advertising Rules Go Back to Court...Again” (24 May 2012), online: Centre for Constitutional Studies <http://ualawccsprod.srv.ualberta.ca/ccs/index.php/constitutional-issues/25other/68-tobacco-advertising-rules-go-back-to-court-again?highlight=WyJ0b2JhY2N vIiwiYWR2ZXJ0aXNpbmciLCJydWxlcyIsImdvIiwiYmFjayIsInRvIiwiY291cnQiLCJhZ2FpbiIsInR vYmFjY28gYWR2ZXJ0aXNpbmciLCJ0b2JhY2NvIGFkdmVydGlzaW5nIHJ1bGVzIiwiYWR2ZXJ 0aXNpbmcgenVsZXMiLCJhZHZlcnRpc2luZyBydWxlcyBnbyIsInJ1bGVzIGdvIiwicnVsZXMgZ28 
government has gone even further; in August 2012, the High Court of Australia upheld the commonwealth government's law on the plain packaging of tobacco products. ${ }^{12}$ This High Court decision, although dealing with a precise area of Australian constitutional law, has garnered worldwide headlines ${ }^{13}$ and has raised the international profile of plain packaging laws as an effective tool to reduce tobacco consumption. ${ }^{14}$ This article seeks to explore the option of plain packaging of cigarettes and determine whether it is a law that Canada should enact. The article will first explain what plain packaging is and will then discuss whether such a law could be enacted in Canada. This analysis focuses on whether a plain packaging law would violate Canada's domestic laws, ${ }^{15}$ particularly Canada’s constitutional laws on the division of powers and the Canadian Charter of Rights and Freedoms. ${ }^{16}$

gYmFjayIsImdvIGJhY2siLCJnbyBiYWNrIHRvIiwiYmFjayB0byIsImJhY2sgdG8gY291cnQiLCJ0b yBjb3VydCIsInRvIGNvdXJ0IGFnYWluIiwiY291cnQgYWdhaW4iXQ==>.

12 JT International SA v Commonwealth of Australia [2012] HCA 43 [JT International]. Australia does not have a bill of rights. As such, the Court did not hear any arguments related to freedom of expression. Rather, the Australian plain packaging decision centred on the protection of property under section 51(xxxi) of the Commonwealth of Australia Constitution Act (Canada's Constitution does not contain a similar provision). Tobacco companies argued that plain packaging laws resulted in the companies' deprivation of the benefits associated with their intellectual property (namely, the trademark and copyrights typically associated with tobacco labelling). This deprivation, it was argued, resulted in a violation of section 51(xxxi) since the Commonwealth was responsible for the deprivation and was not compensating the companies for this deprivation. The tobacco companies also argued that the Commonwealth government had acquired property since the Commonwealth had acquired the use and control over tobacco packaging. The High Court agreed that the tobacco companies were deprived of the right to use and benefit from their intellectual property, but disagreed that it resulted in a violation of section 51 (xxxi). The Court concluded that in order for the laws to violate the constitutional provision, the Commonwealth has to do more than merely take property. The Court, following its decision in the Tasmanian Dam Case (Commonwealth $v$ Tasmania, [1983] HCA 21 [Tasmanian Dam], concluded that section 51(xxxi) requires not only that the government take the property but that it must also acquire a benefit from the property. "To bring the constitutional provision into play it is not enough that legislation adversely affects or terminates a pre-existing right that an owner enjoys in relation to his property; there must be an acquisition whereby the Commonwealth or another acquires an interest in property, however slight or insubstantial it may be” (JT International, ibid at para 42). See also Tasmanian Dam, ibid at para 145. Under the plain packaging laws, the government was not acquiring a benefit; rather, the Commonwealth was merely extinguishing a property right. "In summary, the TPP Act is part of a legislative scheme which places controls on the way in which tobacco products can be marketed. While the imposition of those controls may be said to constitute a taking in the sense that the plaintiffs' enjoyment of their intellectual property rights and related rights is restricted, the corresponding imposition of controls on the packaging and presentation of tobacco products does not involve the accrual of a benefit of a proprietary character to the Commonwealth which would constitute an acquisition. That conclusion is fatal to the case of both JTI and BAT" (see JT International, ibid at para 44).

13 See Matt Siegel, “Australian Court Strikes Down Tobacco Challenge,” The New York Times (15 August 2012), online: The New York Times <http://www.nytimes.com/2012/08/16/business/global/australiancourt-strikes-down-tobacco-challenge-html?pagewanted=all>; Carly Weeks, "Australia's 'plain packaging' cigarette ruling: Bold leadership or draconian?,” The Globe and Mail (15 August 2012), online: The Globe and Mail <http://www.globeandmail.com/life/the-hot-button/australias-plain-pack aging-cigarette-ruling-bold-leadership-or-draconian/article4483363/>; Jonathan Pearlman \& Nathalie Thomas, “Australian court throws out plain packaging challenge,” The Telegraph (16 August 2012) , online: The Telegraph <http://www.telegraph.co.uk/finance/newsbysector/retailandconsumer/9478838/ Australian-court-throws-out-cigarette-plain-packaging-challenge.html>.

14 Numerous governments (including New Zealand, the United Kingdom, Norway, France, South Africa, and India) have since stated that they will consider adopting plain packaging in their respective states. See Philip Hudson, “Tobacco win vindicates Gillard Government’s controversial risk to adopt a plain packaging policy,” The Herald Sun (16 August 2012), online: The Herald Sun <http://www.herald sun.com.au/news/opinion/tobacco-win-vindicates-gillard-governments-controversial-risk-to-adopt-aplain-packaging-policy/story-e6frfhqf-1226451249744\#>. See also, "India mulls plain packaging of cigarettes,” The Herald Sun (5 September 2012), online: The Herald Sun <http://www.heraldsun.com. au/news/breaking-news/india-mulls-plain-packaging-of-cigarettes/story-e6frf7k6-1226465946546>. There are also potential arguments to be made under Canada's international trade obligations. However, these arguments are beyond the scope of the article. In Australia, the plain packaging laws have been challenged using both domestic laws and Australia's international trade obligations, see below note 23. Part I of the Constitution Act, 1982, being Schedule B to the Canada Act 1982 (UK), 1982, c 11 [Charter]. 


\section{Plain Packaging Laws}

While Australia is the first country to officially adopt plain packaging laws for tobacco products, the concept is not new. ${ }^{17}$ Plain packaging requires that tobacco products be sold in plain, unadorned, and uniform packages; this means that a company's trademark or logo cannot appear in its regular style on the tobacco package. ${ }^{18}$ These laws can be quite detailed. For instance, according to Australia’s Tobacco Plain Packaging Regulations 2011:

Any brand, business or company name, or any variant name, appearing on cigarette packs or cigarette cartons must be printed:

(a) in the typeface known as Lucida Sans; and

(b) for a brand, business or company name - no larger than 14 points in size; and

(c) for a variant name - no larger than 10 points in size; and

(d) with the first letter in each word capitalised and with no other upper case letters; and

(e) in a normal weighted regular font; and

(f) in the colour known as Pantone Cool Gray 2C. ${ }^{19}$

Furthermore, the laws can dictate the size, shape, and colour of the tobacco package. It can also detail the designs that may wrap an individual package and dictate what type of wrappers and packaging can be included inside the cigarette container. ${ }^{20}$ In Australia, the

See Becky Freeman, Simon Chapman \& Matthew Rimmer, "The Case for the Plain Packaging of Tobacco Products” (2007) 103:4 Addiction 580 at 587. In 2003, the World Health Organization, recognizing that the harms caused by tobacco consumption affected people regardless of the country of residence, exercised their seldom used powers to create a regulatory regime for tobacco products; the end result was the Framework Convention on Tobacco Control (World Health Organization, WHO Framwork Convention on Tobacco Control (Geneva: World Health Organization, 2003), online: World Health Organization <http://whqlibdoc.who.int/publications/2003/9241591013.pdf > [FCTC]. The FCTC is "a framework for tobacco control measures to be implemented by the Parties at the national, regional and international levels in order to reduce continually and substantially the prevalence of tobacco use and exposure to tobacco smoke" (ibid at 5). See also, Alberto Alemanno \& Enrico Bonadio "Do You Mind My Smoking? Plain Packaging of Cigarettes Under the TRIPS Agreement” (2011) 10:3 John Marshall Review of Intellectual Property Law 450. Since its adoption, over 168 countries have become signatories to the Convention (ibid at 452).

Alemanno \& Bonadio, ibid at 451.

(Cth) Reg 2.4.1.

For instance, Australia's Tobacco Plain Packaging Regulations, ibid, dictate:

Division 2.2 Colour and finish of retail packaging

2.2.1 Colour and finish of primary packaging and secondary packaging

(1) This regulation is made for subparagraph 19 (2) (b) (i) of the Act.

(2) All outer surfaces of primary packaging and secondary packaging must be the colour known as Pantone 448C.

(3) Each inner surface of a cigarette pack or cigarette carton must be white.

(4) The lining of a cigarette pack must be silver coloured foil with a white paper backing.

(5) This regulation does not apply to calibration marks.

Furthermore, Part 2, Div 2.5 of the regulations states:

2.5.1 Mark on wrapper to conceal bar codes

A plastic or other wrapper covering more than one item of primary packaging may be marked with a solid black rectangle to conceal the bar code on each item of primary packaging covered by the wrapper.

\subsubsection{Tear strips on wrappers}

(1) A plastic or other wrapper that covers primary packaging or secondary packaging, or that covers a tobacco product for retail sale, may include one tear strip.

(2) The tear strip must:

(a) be either:

(i) entirely black; or

(ii) entirely transparent and not coloured; and 
plain packaging laws include how each individual cigarette is wrapped. ${ }^{21}$ Basically, plain packaging laws require cigarettes to be packaged in a standardized plain package.

Advocates of plain packaging laws point to studies that indicate that adopting such laws reduces tobacco consumption. Research has shown that there are a myriad of benefits associated with plain packaging laws, including: that plain packaging increases the noticeability and impact of the health warnings; that plain packages are less likely to mislead customers about the harmful nature of the tobacco product; and that plain packaging reduces the attractiveness of the product for all consumers. ${ }^{22}$ These benefits make plain packaging a valuable tool in the fight against tobacco consumption. While advocates trumpet their importance, these laws have been met with resounding disapproval from tobacco companies. $^{23}$

Tobacco companies are generally reluctant to adopt plain packaging for their products because of business implications. Packaging has become an essential advertising tool for the companies. ${ }^{24}$ Accordingly, "we will increasingly see the pack being viewed as a total

(b) form a single continuous straight line of constant width, not wider than

$3 \mathrm{~mm}$, around the circumference of the primary packaging or secondary packaging covered by the wrapper.

(3) However, a transparent and not coloured tear strip may include a single solid black line not more than $15 \mathrm{~mm}$ long indicating where the tear strip begins.

(4) A tear strip on a plastic or other wrapper that covers one cigarette pack must be parallel, and as close as possible, to the bottom edge of the flip-top lid.

(5) A tear strip on a plastic or other wrapper that covers a cigarette carton or more than one cigarette pack must be parallel to any straight edge of the cigarette carton or cigarette packs.

21 See Part 3: Requirements for appearance of tobacco products, ibid.

22 Tobacco: Plain Packaging of Tobacco Products, online: Australian Government Department of Health and Ageing <http://www.health.gov.au/internet/main/publishing.nsf/content/tobacco-plain>. See also The Report of the National Representative Health Task Force, Taking Preventative Action, A Response to Australia: The Healthiest Country by 2020 (May 2010), online: Australia Government <http://www. yourhealth.gov.au/internet/yourhealth/publishing.nsf/Content/1671CBF53AA5E030CA2579540005 F1C3/\$File/6588\%20DoHA\%20Health\%20Strategy_120510.pdf $>$. Furthermore, according to a study prepared for Health Canada, "[a]ll evidence from the various facets of the National Survey of Teens is consistent in that it points to plain and generic packaging having a slight to perhaps moderate effect on smoking uptake among Canadian teens. Since the groups most likely to be affected by such packaging - the vulnerable/naive and experimenters - are the ones going through smoking uptake decision making, plain and generic packaging should have an effect on smoking uptake and cessation among Canadian teens"(see Marvin E Goldberg et al, When Packages Can't Speak: Possible Impacts of Plain and Generic Packaging of Tobacco Products (Ottawa: Health Canada, 1995) at 76). See also the study that concluded that as brand design information was removed from cigarette packaging, they were less appealing; and the participants found that the cigarettes were less satisfying (Daniella Germain, Melanie A Wakefield \& Sarah J Durkin, “Adolescents’ Perceptions of Cigarette Brand Image: Does Plain Packaging Make a Difference?” (2010) 46:4 Journal of Adolescent Health 385. See MA Wakefield, D Germain \& SJ Durkin, “How Does Increasingly Plainer Cigarette Packaging Influence Adult Smokers' Perceptions About Brand Image? An Experimental Study” (2008) 17:6 Tobacco Control 416. Aside from making the product less appealing, plain packaging also makes health warnings more visible thereby adding to the warnings effectiveness (Freeman, Chapman \& Rimmer, supra note 17 at 582-83). See generally, Alemanno \& Bonadio, supra note 17; Andrew D Mitchell, “Australia's Move to the Plain Packaging of Cigarettes and Its WTO Compatibility” (2010) 5:2 Asian Journal of WTO \& International Health Law \& Policy 405 at 408.

23 In Australia, tobacco companies have started litigation, both domestically and internationally, to battle the adoption of plain packaging laws (see generally supra note 12); “Australia - Certain Measures Concerning Trademarks and Other Plain Packaging Requirements Applicable to Tobacco Products and Packaging,” online: The World Trade Organization <http://www.wto.org/english/tratop_e/dispu_e/ cases_e/ds434_e.htm>.

24 It has been argued that the "'product package is the communication life-blood of the firm', the 'silent salesman' that reaches out to customers and that packaging 'act[s] as a promotional tool in its own right'. Cigarette packaging conveys brand identity through brand logos, colours, founts, pictures, packaging materials and pack shapes. The world's most popular cigarette brand, Marlboro, can be identified readily through its iconic red chevron. The Marlboro brand is estimated to be worth \$US27 billion, making it 
opportunity for communications.... Each pack component will provide an integrated function as part of a carefully planned brand or information communications campaign." ${ }^{25}$ In countries, including Canada, where tobacco advertising is heavily regulated, packaging takes on even greater significance: without the ability to advertise in more traditional fashions, companies rely on packaging and retailer displays to serve as advertisement. ${ }^{26}$

Over the course of several decades, the federal government has tried to reduce tobacco consumption in the population by adopting increasingly stringent laws. While the federal government has adopted laws that impact tobacco packaging (that is, warning label requirements), it has yet to implement plain packaging laws. Should Canada choose to adopt plain packaging, it will likely be met with fierce resistance from the tobacco companies. ${ }^{27}$ The next section of the article will examine constitutional law issues surrounding the adoption of plain packaging laws.

\section{Plain Packaging Laws and the Canadian Constitution}

Domestically, there are two potential constitutional arguments that may prevent the adoption of plain packaging laws: the first is an argument based on the constitutional division of powers; the second is an argument based on the freedom of expression guarantee found in section 2(b) of the Charter. This article examines both arguments.

\section{A. Division of PoWers}

The constitutionality of the plain packaging legislation may be challenged by arguing that the legislation is not a valid exercise of the federal government's criminal law power and, as such, the legislation is ultra vires. ${ }^{28}$ Such an argument is unlikely to succeed. In 1988, the federal government enacted the Tobacco Products Control Act. ${ }^{29}$ This Act prohibited, with some exceptions, the advertising of tobacco products, and it also established packaging

the tenth most valuable (all product) brand in the world” (Freeman, Chapman \& Rimmer, supra note 17 at 581 [footnotes omitted]. See also Mitchell, supra note 22.

Nigel Mawditt, "Putting Pack Opportunities into the Frame" (2006) 36 World Tobacco 212. See also, Mitchell, ibid.

G Eindhoven, "Elegant Packs Promote Image, Defend Property Rights" (1999) 16 World Tobacco 170. See also, Mitchell, ibid. Studies have shown that 50 percent of smokers are not able to distinguish between similar cigarettes; companies rely on images and branding to invoke brand loyalty and keep consumers (Germain et al, supra note 22 at 388-89).

27 Tobacco companies have a history of litigating matters that reduce their ability to advertise tobacco products. See supra notes 12 and 23. See also RJR-MacDonald Inc v Canada (Attorney General), [1995] 3 SCR 199 [RJR-MacDonald]; Canada (Attorney General) v JTI-Macdonald Corp, 2007 SCC 30, [2007] 2 SCR 610 [JTI-MacDonald].

$28 \quad$ In Canada, jurisdiction over health matters is divided between the federal and provincial governments; the bulk of the jurisdiction rests with the provincial governments. As Martha Jackman stated

[w] hile "health" is not an expressly enumerated subject under section 91 or 92 of the Constitution

Act 1867, section 92(7) grants the provinces exclusive jurisdiction in relation to the establishment, maintenance and management of hospitals. Section 92(13) and section 92(16) provide for provincial jurisdiction over "property and civil rights" and "local or private" matters in the province. Taken together, these provisions give the provinces primary constitutional responsibility for health care and health care services in Canada.

Martha Jackman, "Constitutional Jurisdiction Over Health in Canada” (2000) 8 Health LJ 95 at 110. As such, the federal government cannot use a health power to enact plain packaging laws and must rely on a different assigned power to justify such a law - most likely it would be the criminal law power. SC 1988, с 20. 
requirements for tobacco products. ${ }^{30}$ Tobacco companies protested the adoption of the Act and challenged the legislation. One of the key arguments made challenging the constitutionality of the legislation was that the Act was not a proper exercise of the federal government's criminal law power. In 1995, the Supreme Court of Canada ruled that the Act was a valid exercise of the federal government's criminal law power. ${ }^{31}$ This section of the article explores the Court's ruling in RJR-MacDonald on the issue of the criminal law power and will then discuss why the Court would likely adopt a similar reasoning if plain packaging laws were challenged on this basis.

Historically, the Supreme Court of Canada has given the federal government's power over criminal law matters a broad scope, stating that " $[\mathrm{t}]$ he terms of s. 91(27) of the Constitution must be read as assigning to Parliament exclusive jurisdiction over criminal law in the widest

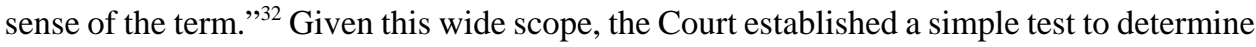
whether a law falls within the federal government's criminal law jurisdiction: the law must prohibit an act with penal consequences and there must be a public purpose underlying the prohibition. ${ }^{33}$ In its Margarine Reference decision, the Court provided some guidance as to what can be considered a public purpose. The Court stated "[i]s the prohibition ... enacted with a view to a public purpose which can support it as being in relation to criminal law? Public peace, order, security, health, morality: these are the ordinary though not exclusive ends served by that law."34

In RJR-MacDonald, the Supreme Court of Canada applied this test to determine whether the Tobacco Products Control Act was a valid enactment pursuant to the federal government's criminal law jurisdiction. The legislation clearly met the first part of the test. The legislation created prohibited acts: namely, the advertisement of tobacco, the promotion of tobacco products, and the sale of the products without proper labeling. ${ }^{35}$ Furthermore, these prohibited acts were, by section 18 of the Act, accompanied by penal sanctions. These two elements meant that the law was, prima facie, a criminal matter. The Court then turned to examine whether the law was enacted as a result of a public purpose. the tobacco product (ibid).

RJR-MacDonald, supra note 27. Note that the tobacco legislation in RJR-MacDonald was struck down by the Court on the basis that it infringed the freedom of expression as protected by section 2(b) of the Charter.

$32 \quad$ Scowby v Glendinning, [1986] 2 SCR 226 at 238. See also RJR-MacDonald, ibid at para 28.

33 Originally, the Privy Council defined the criminal law power to include any prohibited act that had penal consequences (see Proprietary Articles Trade Association v Attorney-General for Canada, [1931] AC 310 at 324). This definition was subsequently limited to include the restriction that the prohibition must be based on an underlying public purpose in the Supreme Court of Canada's Margarine Reference decision (Reference re Validity of Section 5(a) of the Dairy Industry Act, [1949] SCR 1 at 49-50 [Margarine Reference]). Recently, the Supreme Court of Canada has stated that such power must be limited to maintain the balance of powers between the two levels of government. "To this end, criminal laws for the protection of health must address a 'legitimate public health evil'” (Reference re Assisted Human Reproduction Act, 2010 SCC 61, [2010] 3 SCR 457 at para 52).

$34 \quad$ Margarine Reference, ibid at 50.

35 See RJR-MacDonald, supra note 27 at para 29. See also s 4-9 of the Tobacco Products Control Act, supra note 29. 
The Court examined section 3 of the Act, the Act's purpose clause, to determine its purpose. Accordingly, the Act sought

(a) to protect the health of Canadians in light of the conclusive evidence implicating tobacco use in the incidence of numerous debilitating and fatal diseases;

(b) to protect young persons and others, to the extent that is reasonable in a free and democratic society, from inducements to use tobacco products and consequent dependence on them; and

(c) to enhance public awareness of the hazards of tobacco use by ensuring the effective communication of pertinent information to consumers of tobacco products. ${ }^{36}$

The Court, after considering extensive research on the harms associated with the tobacco consumption, ${ }^{37}$ concluded that the detrimental "health effects of tobacco consumption are both dramatic and substantial" 38 and that the protection of Canadians from the risks associated with tobacco consumption is a valid public health concern. ${ }^{39}$ The Court concluded that, in line with the Margarine Reference decision, which stated that the protection of public health is a legitimate aim of criminal law, the Tobacco Products Control Act falls within the federal government powers under criminal law. ${ }^{40}$

The Supreme Court of Canada has already considered whether the federal government can use its jurisdiction over criminal law to control tobacco consumption. However, this was not a unanimous decision. More specifically, the dissent, written by Justice Major with Justice Sopinka concurring, concluded that Parliament may not impose an "advertising ban on tobacco products, trade marks, and brand names under its criminal law power.”41

The dissent took issue with the test for determining the criminal law power and argued that "legislation which merely contains a prohibition and a consequent penalty cannot be upheld as a valid exercise of Parliament's criminal law power unless the legislation also addresses a 'typically criminal public purpose." 42 In order to determine whether the legislation addresses a criminal purpose, the dissent argued that the test should examine whether "the act or omission is sufficiently harmful to the state, or to persons or property within the state to warrant the exercise of Parliament's criminal law power ... [it] must pose a significant,

RJR-MacDonald, ibid at para 30; Tobacco Products Control Act, ibid at s 3.

The Court examined scientific evidence that found a causal connection between smoking and numerous life threatening diseases. Furthermore, the Court stated that this evidence was accepted by "all leading health professional organizations and by many governments and international agencies" (RJRMacDonald, ibid at para 31).

Ibid at para 32.

Ibid at paras 30-32.

Once it has been proven that the legislation meets the test to fall within the criminal law power, the legislation is considered to be validly enacted unless it can be characterized as a "colourable" intrusion into provincial jurisdiction. This means that the court has to determine whether the federal government enacted the legislation with an underlying purpose or intention to encroach upon areas that were within the provincial jurisdiction. See $R v$ Morgentaler, [1993] 3 SCR 463 at 489. In the case of $R J R$ MacDonald, the Court concluded that that there was "no evidence in the present cases that Parliament had an ulterior motive in enacting this legislation, or that it was attempting to intrude unjustifiably upon provincial powers under ss. 92(13) and (16)" (RJR-MacDonald, ibid at para 33).

$41 \quad$ RJR-MacDonald, ibid at para 193. Justice Major did agree that Parliament could prevent the sale of tobacco products that did not have proper warning labels.

Ibid at paras 198. 
grave and serious risk of harm to public health, morality, safety or security." "43 Using this test, the dissent examined whether a prohibition on advertising tobacco products fell within the proper purview of criminal law and the dissent concluded that it did not.

While Justice Major did acknowledge that tobacco advertising may be an undesirable form of commercial expression, he concluded that this undesirability was not sufficient enough to make it criminal. ${ }^{44} \mathrm{He}$ reasoned that "the Act is too far removed from the injurious or undesirable effects of tobacco use to constitute a valid exercise of Parliament's criminal law power. Legislation prohibiting all advertising of a product which is both legal and licensed for sale throughout Canada lacks a typically criminal public purpose." 45 The dissent found it illogical to criminalize an activity, in this instance tobacco advertising, when the underlying activity that the Act seeks to eliminate, the consumption of tobacco products, is still legal. ${ }^{46}$

So what does this mean for plain packaging laws? The majority of the Court concluded that the federal government, pursuant to its criminal law powers, has jurisdiction to pass laws for the protection of public health. Furthermore, the majority also concluded that tobacco use is a public health concern and that Parliament can, therefore, enact laws that seek to control and eliminate the use of such products. Despite this, the dissent left open the possibility of re-litigating this matter by arguing that the prohibition against the use of advertising using legal trademarks and packaging does not fall within the criminal law jurisdiction. As the dissent argued, trademarks are legally protected and registered pursuant to federal laws; their use is "in itself not sufficiently dangerous or harmful to justify criminal sanctions."

Following the decision in RJR-MacDonald, the federal government made changes to the Tobacco Products Control Act and subsequently passed the Tobacco Act. The constitutionality of this legislation was challenged in the case of JTI-Macdonald. ${ }^{48}$ The constitutionality argument was based on a violation of section 2(b) of the Charter. In relation to the federal government's criminal law power, the Supreme Court of Canada stated that "[r]estrictions on tobacco advertising are a valid exercise of Parliament's criminal law power." 49 This seems to indicate that, as far as the Court is concerned, the matter has been decided, and the concern raised by the dissent in RJR-MacDonald is not a significant issue. As such, it is highly unlikely that the Court would, in the case of plain packaging laws, part from its reasoning in JTI-Macdonald and RJR-MacDonald on the issue of jurisdiction under the criminal law power: "[p]ut bluntly, tobacco kills. Given this fact, can Parliament validly employ the criminal law to prohibit tobacco manufacturers from inducing Canadians to consume these products, and to increase public awareness concerning their hazards of their use? In my view, there is no question that it can." 50 


\section{B. CANADIAN CHARTER OF RIGHTS AND FREEDOMS}

While it would seem unlikely that plain packaging laws would be declared unconstitutional based on an argument centered on the use of Parliament's criminal law power, another constitutional law argument remains open. The strongest argument against plain packaging laws would be based on the Charter. The following section examines whether tobacco packaging can be considered expression for the purposes of the Charter and whether plain packaging laws violate section 2(b). The analysis then turns to examine whether such a potential violation of freedom of expression can be saved by section 1 of the Charter.

\section{FREEDOM OF EXPRESSION}

Freedom of expression has been referred to as a "fundamental right" with historical roots that date back several hundreds of years. ${ }^{51}$ Free expression is a necessity in a democratic society; it is essential in the pursuit of truth and allows for the building of a competitive market-place of ideas. It is also essential for personal growth and self-realization. ${ }^{52}$ In Canada, the right to free expression is protected under section 2(b) of the Charter, and this section states:

2. Everyone has the following fundamental freedoms:

(b) freedom of thought, belief, opinion and expression, including freedom of the press and other media of communication.

If plain packaging laws were adopted by Parliament, such laws may, arguably, violate section 2(b) of the Charter. In 1989, the Supreme Court of Canada examined the freedom of expression guarantee in the Charter and provided an analytical framework for resolving section 2(b) cases; this framework is still used. ${ }^{53}$ The test, established by the Court in Irwin Toy, consists of two parts: first, the court must determine whether the activity falls within the protected sphere of free expression; then, the court will examine whether the legislation infringes, either in purpose or effect, the protected sphere of free expression. ${ }^{54}$ This section begins by exploring the types of expression that are protected under section 2(b) and then examines the analytical framework of section 2(b) to determine whether the packaging of tobacco products is an activity that attracts protection under that provision.

See Attorney General of Canada v Law Society of British Columbia, [1982] 2 SCR 307 at 362. See also Caroline Reid, "Freedom of Expression, Commercial Expression and Tobacco in Canada” (2008) 39:2 VUWLR 343 at 347. See also Irwin Toy Ltd v Quebec (AG) [1989] 1 SCR 927 [Irwin Toy] where the Court stated that the protection of expression is fundamental "because in a free, pluralistic and democratic society we prize a diversity of ideas and opinions for their inherent value both to the community and to the individual” (ibid at 968).

52 See Robert J Sharpe, “Commercial Expression and the Charter” (1987) 37:3 UTLJ 229 at 232. See also Ford v Quebec (Attorney General), [1988] 2 SCR 712 [Ford]; Reid, ibid at 347.

$53 \quad$ Irwin Toy, supra note 51.

$54 \quad$ Ibid. See also Baier v Alberta, 2007 SCC 31, [2007] 2 SCR 673 at para 19 [Baier]. 


\section{a. $\quad$ Step One: The Protected Sphere of Free Expression}

One of the Supreme Court of Canada's first decisions on the freedom of expression was Ford. ${ }^{55}$ The Court in Ford outlined the principles and values that underlie the Charter's freedom of expression guarantees. The principles and values are:

1. Seeking and attaining truth is an inherently good activity;

2. Participation in social and political decision-making is to be fostered and encouraged; and

3. The diversity in forms of individual self-fulfillment and human flourishing ought to be cultivated in an essentially tolerant, indeed welcoming, environment not only for the sake of those who convey a meaning, but also for the sake of those to whom it is conveyed. ${ }^{56}$

Despite these early pronouncements in Ford, it was not until its decision in Irwin Toy ${ }^{57}$ that the Supreme Court of Canada stated its understanding of the meaning of freedom of expression as protected by section 2(b). ${ }^{58}$ The Court was quick to acknowledge that not all forms of activity are protected by freedom of expression; ${ }^{59}$ in order to determine what types of activities are protected by freedom of expression, the Court had to define expression. When analyzing section 2(b), the Court stated that "expression" has both a form and content and that "[a]ctivity is expressive if it attempts to convey meaning." ${ }^{60}$ Accordingly, expression can be conveyed through a myriad of forms, including but not limited to: art, physical gestures, speaking or writing. However, violent acts will not be afforded section 2(b) protection. ${ }^{61}$ Furthermore, protection under section 2(b) is meant to "ensure that everyone can manifest their thoughts, opinions, beliefs, indeed all expressions of the heart and mind, however unpopular, distasteful or contrary to the mainstream." ${ }^{22}$ While the Court has given a very broad definition to freedom of expression, it has also stated "[w]hile some types of expression, like political expression, lie closer to the core of the guarantee than others, all are

Ford, supra note 52. In Ford, the Court had to decide whether the government's law that restricted one's choice of language violated section 2(b). The Court concluded "[l] anguage is so intimately related to the form and content of expression that there cannot be true freedom of expression by means of language if one is prohibited from using the language of one's choice. Language is not merely a means or medium of expression; it colours the content and meaning of expression" (Ford, ibid at 748). While the Court did state that commercial expression can be protected by section 2(b), the reasons for such a decision required, in the Court's opinion, further elaboration. "Whereas it was sufficient in Ford to reject the submission that the guarantee of freedom of expression does not extend to signs having a commercial message, this case [Irwin Toy] requires a determination whether regulations aimed solely at commercial advertising limit that guarantee. This, in turn, requires an elaboration of the conclusion reached in Ford that there is no sound basis on which to exclude commercial expression, as a category of expression, from the sphere of activity protected by s. 2(b) of the Canadian Charter" (Irwin Toy, supra note 51 at 967).

56 Irwin Toy, ibid at 976 where the Court summarized the principles and values stated in Ford.

57 In Irwin Toy, the Court had to consider whether sections 248 and 249 of Quebec's Consumer Protection Act, RSQ, c P-40.1 were unconstitutional. These sections prohibited commercial advertising that targeted children under the age of thirteen. Among the arguments submitted to the Court was that these sections violated the company's freedom of expression under section 2(b) of the Charter, see Irwin Toy, ibid at para 1.

$58 \quad$ Ibid. See also Robin Elliot, "Back To Basics: A Critical Look at the Irwin Toy Framework for Freedom of Expression” (2011) 15:2 Rev Const Stud 205 at 208.

$59 \quad$ The Court stated "[c]learly, not all activity is protected by freedom of expression, and governmental action restricting this form of advertising only limits the guarantee if the activity in issue was protected in the first place" (Irwin Toy, ibid at 967).

See Irwin Toy, ibid at 968.

Ibid at 970 .

Ibid at 968 . 
vital to a free and democratic society."63 As a result of the purpose of section 2(b), the Court has stated that activity cannot be excluded from protection based on the content or meaning that is being conveyed. ${ }^{64}$ Essentially, the Supreme Court of Canada, in their definition of expression, extended section 2(b) protection to almost any non-violent activity that attempts to or does convey a message. ${ }^{65}$

Such a broad definition of expression has meant that section 2(b) protection has been afforded to a wide range of activity, including commercial advertising to children, communicating for the purposes of prostitution, child pornography, and running in an election. ${ }^{66}$ Furthermore, with such a broad definition of expression, the Court has concluded that commercial expression is considered expression for the purposes of section 2(b): "Given the earlier pronouncements of this Court to the effect that the rights and freedoms guaranteed in the Canadian Charter should be given a large and liberal interpretation, there is no sound basis on which commercial expression can be excluded from the protection of section $2(b)$ of the Charter. " ${ }^{67}$ In fact, the Court has recognized the inherent value of advertising as a form of expression; it has stated that advertising allows individuals to make an informed economic choice which contributes to individual autonomy and fulfillment. ${ }^{68}$ Once it is determined that the activity in question falls within the protected sphere of section 2(b), the court will then turn to the second part of the test.

$R v$ Sharpe, 2001 SCC 2, [2001] 1 SCR 45 at para 23 [Sharpe].

Ibid at para 43.

Since its very broad definition of expression in Irwin Toy, namely that expression is any activity that conveys or attempts to convey meaning, the Court has further restricted the definition. For instance, as stated in Irwin Toy, violent expression is not protected. In certain circumstances, the method or location of the expression may eliminate the section 2(b) guarantee (Baier, supra note 54 at para 20). In Montréal (City of) v 2952-1366 Québec Inc, 2005 SCC 62, [2005] 3 SCR 141 at para 74 [Montréal], the Court clarified the test for deciding whether section 2(b) protection attached to expression on public property. According to the Court, in order to determine whether the location of the expression removes it from protection, the following test must be applied:

The basic question with respect to expression on government-owned property is whether the place is a public place where one would expect constitutional protection for free expression on the basis that expression in that place does not conflict with the purposes which s. 2(b) is intended to serve, namely (1) democratic discourse, (2) truth finding and (3) self-fulfillment. To answer this question, the following factors should be considered:

(a) the historical or actual function of the place; and

(b) whether other aspects of the place suggest that expression within it would undermine the values underlying free expression.

(Ibid.) Furthermore, the rights protected in section 2(b) are negative rights; while the government must not interfere with freedom of expression, it is not under an obligation to provide a platform for individuals to express themselves (see Baier at para 21). As Justice L'Heureux-Dube stated "the freedom of expression contained in s. 2(b) prohibits gags, but does not compel the distribution of megaphones" (Haig $v$ Canada, [1993] 2 SCR 995 at 1035 [Haig]). While the traditional view of freedom of expression being a negative right remains true, if the legislation is under inclusive and the plaintiff is able to meet the test established in Dunmore (this case discussed section 2(d), freedom of association rights; but the Court stated that the test applied to section 2 in general) and subsequently applied in Baier, the government will be compelled to provide the platform (see Baier, ibid; Dunmore $v$ Ontario (Attorney General), 2001 SCC 94, [2001] 3 SCR 1016 [Dunmore]). See also Greater Vancouver Transportation Authority v Canadian Federation of Students - British Columbia Component, 2009 SCC 31, [2009] 2 SCR 295. Chanakya Sethi, "Beyond Irwin Toy: A New Approach to Freedom of Expression under the Charter" (2012) 17 Appeal 21.

Ford, supra note 52 at 766-67. See also Irwin Toy, ibid.

Rocket v Royal College of Dental Surgeons of Ontario, [1990] 2 SCR 232 at para 4 [Rocket]. 
b. Step Two: Infringement by Purpose or Effect

The next part of the section 2(b) test requires the court to examine whether the government action controlled, by purpose or effect, the attempt to convey meaning through the activity. At this stage, the court must focus on the purpose and effect of the legislation. The Court has given further guidance as to how this analysis should take place:

[T] he legislation's purpose is the initial test of constitutional validity and its effects are to be considered when the law under review has passed or, at least, has purportedly passed the purpose test. If the legislation fails the purpose test, there is no need to consider further its effects, since it has already been demonstrated to be invalid. Thus, if a law with a valid purpose interferes by its impact, with rights or freedoms, a litigant could still argue the effect of the legislation as means to defeat its applicability and possibly its validity. In short, the effects test will only be necessary to defeat legislation with a valid purpose; effects can never be relied upon to save legislation with an invalid purpose. ${ }^{69}$

If the legislation specifically seeks to control expression, it will be considered a violation of the freedom of expression because of purpose. Furthermore, according to the test laid out in Big M Drug Mart, even if the purpose of the government action did not control or restrict attempts to convey a meaning, the legislation can still be found to violate section 2(b) if the effects of the legislation control or restrict the rights protected by section 2(b). In Irwin Toy, the Court stated that in order to demonstrate that the effects of the legislation render the legislation in violation of section 2(b), the "plaintiff must state her claim with reference to the principles and values underlying the freedom."

\section{FREEDOM OF EXPRESSION AND PLAIN PACKAGING LAWS}

So what does this test mean in regards to packaging of tobacco products? To start, a court will have to answer the question of whether the packaging of tobacco products falls within the scope of freedom of expression, and it would likely conclude that tobacco packaging is expression. As discussed, tobacco packages are designed to convey a meaning and have expressive content. Furthermore, there is not any basis for excluding that form of activity from the sphere of protected activity. In RJR-MacDonald, the Attorney General conceded that the prohibition on advertising was a violation of the tobacco's company freedom of expression under section 2(b).$^{71}$ In the 2007 decision in JTI-Macdonald, the Attorney General also conceded a violation of freedom of expression on a majority of the provisions in the Tobacco Act. ${ }^{72}$

One of the only provisions where the Attorney General was unwilling to concede a violation of the freedom of expression centred on the use of the size of warning labels on tobacco packaging. The Attorney General argued that because the tobacco companies could still use 50 percent of the package to advertise their products, the companies were not hindered from displaying their message of choice nor were they deprived "of a vehicle for

$R v$ Big M Drug Mart Ltd, [1985] 1 SCR 295 at 334 [Big M Drug Mart]. Irwin Toy, supra note 51 at 976.

RJR-MacDonald, supra note 27.

For instance, the Attorney General conceded on provisions related to lifestyle advertising, false promotion, and advertising appealing to young persons, among others (JTI-MacDonald, supra note 27). 
communicating their message.”73 The Supreme Court of Canada disagreed; the Court reasoned that, given the broad definition of expressive activity, "the requirement that manufacturers place the government's warning on one half of the surface of their package arguably rises to the level of interfering with how they choose to express themselves."74

Since the Court has ruled a restriction of 50 percent of the tobacco companies' packaging violated the freedom of expression, a law which restricts 100 percent of the package would be a clear violation of the freedom of expression guarantee. Furthermore, the argument that tobacco companies would still be able to display their message of choice would not be applicable to plain packaging legislation. Under plain packaging legislation, the government would completely outlaw the use of packaging as a method of advertising, thereby preventing the company from conveying any expressive content. The Supreme Court of Canada has consistently found that prohibitions against the engagement in commercial expression by advertising are a violation of section 2(b), and the same conclusion would apply to plain packaging laws.

While there is little doubt that plain packaging legislation would be considered a violation of section 2(b) of the Charter, the analysis does not end there. In Canada, the rights protected under the Charter are not limitless; this means that the rights protected under section 2(b) can be limited if the government can meet the proper justification threshold for doing so. As the Court stated in Sharpe,"freedom of expression is not absolute. Our Constitution recognizes that Parliament or a provincial legislature can sometimes limit some forms of expression."75 Pursuant to section 1 of the Charter, "[t]he Canadian Charter of Rights and Freedoms guarantees the rights and freedoms set out in it subject only to such reasonable limits prescribed by law as can be demonstrably justified in a free and democratic society." ${ }^{\text {"T }}$ The next section of the article examines the test under section 1 to determine whether plain packaging laws can be demonstrably justified in a free and democratic society.

\section{SECTION 1 JUSTIFICATION}

Section 1 of the Charter clearly states that the rights contained in the Charter are not absolute; the government can restrict the rights if it can meet the section requirements. When challenging the constitutionality of the law, judicial review of the law must follow two separate steps: the first step requires the court to decide whether the government act infringes upon one of the protected rights. If it does, the court must then consider whether the government act is one that "can be demonstrably justified in a free and democratic society."77 This section examines the justification test for section 1, and then examines how such an analysis may be applied to the plain packaging laws.

When contemplating the meaning of section 1, the Court looked to the purpose of the provision for guidance to determine the appropriate test. Accordingly, there are two purposes to section 1: first, it explicitly provides a constitutional guarantee for the rights and freedoms

JTI-MacDonald, ibid at para 131.

Ibid at para 132.

Sharpe, supra note 63 at para 22.

Charter, supra note 16, s 1.

Peter W Hogg, Constitutional Law of Canada, Student ed. (Toronto: Carswell, 2006) at 826. 
set out in the Charter; ${ }^{78}$ second, it provides the criteria by which any limit of those rights must be measured against. ${ }^{79}$ Furthermore, the Court stated that it must be remembered that a section 1 analysis examines a government action that limits a right that is considered to be the supreme law of the country. ${ }^{80}$ Finally, the Court also considered the underlying principles of the Constitution, including "respect for the inherent dignity of the human person, commitment to social justice and equality, accommodation of a wide variety of beliefs, respect for cultural and group identity, and faith in social and political institutions which enhance the participation of individuals and groups in society," because of section 1's mention of Canada's free and democratic society. ${ }^{81}$ Given the purposes of the section, a test had to be carefully constructed to ensure that it fulfills the intentions of section 1 . The Supreme Court of Canada established the test for section 1 in its decision in Oakes: ${ }^{82}$

\footnotetext{
First, the objective of the legislation must be pressing and substantial. Second, the means chosen to attain this legislative end must be reasonable and demonstrably justifiable in a free and democratic society. In order to satisfy the second requirement, three criteria must be satisfied: (1) the rights violation must be rationally connected to the aim of the legislation; (2) the impugned provision must minimally impair the Charter guarantee; and (3) there must be proportionality between the effect of the measure and its objective so that the attainment of the legislative goal is not outweighed by the abridgement of the right. ${ }^{83}$
}

While the test has been judiciously crafted, the Court has been quick to state that the test is not meant to be applied in a rigid and formalistic manner: "a particular right or freedom may have a different value depending on the legislative context." ${ }^{44}$ Thus, the Court has recognized that the section 1 justification test must examine the context surrounding the laws. Furthermore, when the law infringes the freedom of expression, the reviewing court must take into account the type of expression that was violated.

As discussed, freedom of expression was protected to allow for participation in the political process, contributions to the marketplace of ideas, or for artistic self-fulfilment; expression that is directly tied to these types of activities deserves the utmost constitutional protection. ${ }^{85}$ Commercial expression, although protected by the Charter, does not strike at the core of expressive content; as the Supreme Court of Canada stated, "not all expression is equally worthy of protection. Nor are all infringements of free expression equally serious." ${ }^{86}$ Accordingly, when a court is looking at the Oakes test, it will apply the test more

$R v$ Oakes, [1986] 1 SCR 103 at 135-36 [Oakes].

Ibid.

Ibid. As Justice Wilson stated, "it is important to remember that the courts are conducting this inquiry in light of a commitment to uphold the rights and freedoms set out in the other sections of the Charter" (Singh $v$ Minister of Employment and Immigration, [1985] 1 SCR 177 at 218).

Oakes, supra note 78 at 136.

Oakes, ibid. This test has been refined in Dagenais v Canadian Broadcasting Corp, [1994] 3 SCR 835; Thomson Newspapers Co v Canada (Attorney General), [1998] 1 SCR 877. See also Sharpe, supra note 63 at para 78 .

Egan v Canada, [1995] 2 SCR 513 at para 182. See also Little Sisters Book and Art Emporium v Canada (Minister of Justice), 2000 SCC 69, [2000] 2 SCR 1120 at para 143.

Sharpe, supra note 63 at para 154. See also Edmonton Journal v Alberta (Attorney General), [1989] 2 SCR 1326 at 1355-56 [Edmonton Journal]. See Christopher D Bredt, "The Right to Equality and Oakes: Time for Change" (2009) 27 NJCL 59 at 61, where he states "if Oakes is read closely, it becomes clear that the Court openly acknowledged that the approach to justifying the infringement of constitutionally protected rights would require a case-by-case analysis, with careful attention to the nature of the specific right at issue, and the nature of the infringement."

See Sharpe, ibid; R v Keegstra, [1990] 3 SCR 697 [Keegstra]; Rocket, supra note 68.

Edmonton Journal, supra note 84; Rocket, ibid at 1355-56. 
strictly if the violation of expression is against an activity that seeks to fulfil one of the core goals of the freedom of expression. This stage of the analysis will require the court to conduct "an assessment of the impact of the ban on free expression." ${ }^{87}$

What does all of this mean for the plain packaging of tobacco products? Essentially, when applying the section 1 justification test, a court, in assessing the impact of this ban, will have to examine the nature of the expression that is at issue..$^{88}$ In terms of plain packaging of tobacco products, the expression that is limited by the laws would be that of tobacco companies who wish to impart brand information about their product to their potential customers; the tobacco companies are not motivated to make this expression because of political process, contributing to the market place of ideas, or artistic self-fulfilment. Instead, rather their motivation is economic. Similarly to the prohibitions that were placed on expression in Irwin Toy and Rocket, the tobacco companies' losses from the limitation placed on this type of expression are economic. In both Irwin Toy and Rocket, the Supreme Court of Canada concluded that this type of restriction on expression is easier to justify than other types of infringements of section 2(b). ${ }^{89}$

In Rocket, the Court did acknowledge that there are conflicting rights: namely, the right of the consumer to make an informed choice versus the fact that expression is created only to increase profits. ${ }^{90}$ In fact, the Court recognized that, in almost all cases of commercial expression, there will be conflicting interests. In Rocket, Justice McLachlin (as she then was) reasoned that commercial advertisement did have important expressive interests because it allowed customers to make informed choices about dental services. This was considered a relatively important consumer decision..$^{91}$ The Court, in Irwin Toy, did not pay heed to the consumer choice aspect of the expression because the advertisement was aimed towards children and the Court did not believe that children's consumer choice rights deserved significant protection..$^{92}$ In fact, in Irwin Toy, the Court "suggested that substantial latitude should be given to legislatures that act to protect a vulnerable group." ${ }^{93}$ While the Court recognized that the consumer information element was more persuasive in Rocket than it was in Irwin Toy, it nevertheless concluded that such considerations were not as significant as the fact that consumers should be protected from unregulated advertisement about the dental industry and, as such, some deference needed to be shown when applying the section 1 test. ${ }^{94}$

In the case of plain packaging, the arguments in favour of consumer choice and awareness are not as strong they were in Rocket. Quite simply, in Rocket, the provincial legislature was limiting the right to make an informed choice about an important health decision, whereas with plain packaging laws, Parliament is denying the right of a company to advertise products that are known carcinogens. Parliament is seeking to protect vulnerable groups (including teens, who are particularly susceptible to tobacco branding, and other addicted individuals) by restricting advertising and branding of tobacco products. Given the general

Toronto Star Newspapers Ltd v Canada, 2010 SCC 21, [2010] 1 SCR 721 at para 33.

Ibid. See also Canadian Broadcasting Corp v New Brunswick (Attorney General), [1996] 3 SCR 480. Irwin Toy, supra note 51; Rocket, supra note 68 at 248.

Rocket, ibid.

Rocket, ibid.

Irwin Toy, supra note 51; Rocket, ibid.

Rocket, ibid.

Ibid. 
context surrounding tobacco advertising and the type of expression that is being prohibited by plain packaging laws, it is likely that the court will conclude that these types of violations are not as serious as others, and the justification test should be applied to reflect that reality. The article will now turn to examine the justification test.

\section{a. Prescribed by Law}

The first part of the Oakes test requires that the limit on the Charter right be "prescribed by law." According to Peter Hogg, these words "make clear that an act that is not legally authorized can never be justified under s.1, no matter how reasonable or demonstrably justified it may appear to be.” While the Supreme Court of Canada has yet to provide a complete analysis of the requirement "prescribed by law," it typically entails both an accessibility and precision requirement. ${ }^{95}$ The accessibility requirement, based on the constitutional principle of the rule of law, requires that the public must be able to access the law. ${ }^{96}$ The Court has stated that statutes, regulations, and common law rules do meet the accessibility standard. ${ }^{97}$ The precision requirement, also based on the rule of law principle, requires that a law must be written with enough precision to allow the public to guide their behaviour accordingly. ${ }^{98}$ In Irwin Toy, the Supreme Court of Canada has stated that a law would fail the "prescribed by law" requirement for lack of precision "where there is no intelligible standard and where the legislature has given a plenary discretion to do whatever seems best in a wide set of circumstances." $" 99$

In regards to plain packaging of tobacco products, it seems likely that the government would be able to meet the first part of the Oakes test. Plain packaging laws would be codified in statute (with relevant regulations). Therefore, such, the accessibility portion of the "prescribed by law" test would be met. Furthermore, if Canada adopted plain packaging legislation similar to Australia's, the laws would not fail the test for a lack of precision. Plain packaging laws in Australia have been subject to significant judicial review by Australian courts and have not been void for vagueness; ${ }^{100}$ it is unlikely that Canadian laws adopting similar requirements would provide no intelligible standard or grant "plenary discretion to do whatever seems best in a wide set of circumstances." ${ }^{101}$ As such, it is likely that plain packaging tobacco laws would meet the first part of the Oakes test and satisfy the "prescribed by law" requirement.

Hogg, supra note 77 at 837.

Ibid at 836-37.

See $R v$ Therens, [1985] 1 SCR 613 at 645 where it was stated, "[t]he limit will be prescribed by law within the meaning of s. 1 if it is expressly provided for by statute or regulation, or results by necessary implication from the terms of a statute or regulation or from its operating requirements. The limit may also result from the application of a common law rule.”

Hogg, supra note 77 at 837.

Irwin Toy, supra note 51 at 983.

See supra note 12.

Irwin Toy, supra note 51 at 983 . See also supra note 12. 


\section{b. Pressing and Substantial Objective}

According to the Oakes test, after establishing that the government action has been prescribed by law, the analysis must then examine whether the action has a pressing and substantial objective. The Supreme Court of Canada concluded that only state actions that have a pressing and substantial objective are important enough to justify limiting protected Charter rights. ${ }^{102}$

When a court seeks to determine whether the objective is pressing and substantial, it has to focus on the purpose of the legislation. ${ }^{103}$ The court is not required to accept a single purpose for the legislation; rather, like the Supreme Court of Canada has stated in Alberta v. Hutterian Brethren of Wilson Colony, that a court "may deal both with the primary goal of an enabling law and with collateral concerns resulting from measures adopted to achieve this goal." ${ }^{104}$ Given the requirement of a pressing and substantial objective, Parliament would have to identify what objective the plain packaging legislation was trying to accomplish.

In its previous dealings with tobacco advertising controls, the Canadian government has typically cited public health concerns as the purpose for such restrictions. In RJRMacDonald, the government stated that the legislation was enacted with an "objective of protecting Canadians from the health risks associated with tobacco use, and informing them about these risks.” ${ }^{105}$ Similarly, in JTI-MacDonald, the purposes of the challenged Tobacco Act were "to provide a legislative response to a national public health problem of substantial and pressing concern"; "to protect the health of Canadians in light of conclusive evidence implicating tobacco use in the incidence of numerous debilitating and fatal diseases"; "to protect young persons and others from inducements to use tobacco products"; "to protect the health of young persons by restricting access to tobacco products"; and "to enhance public awareness of the health hazards of using tobacco products.”106 Plain packaging legislation, which is meant to reduce tobacco consumption, would have a purpose similar to the Tobacco Act and the Tobacco Act's predecessor, Tobacco Products Control Act. Is the public health purpose behind the tobacco advertising restrictions pressing and substantial?

Accordingly, "an object will be deemed proper if it is for the realization of collective goals of fundamental importance.”107 In JTI-MacDonald, the Supreme Court of Canada acknowledged that legislation that seeks to protect the health of Canadians and responds to a public health problem can meet the threshold of pressing and substantial. Furthermore, if Parliament properly tailors the purpose of the legislation by linking it to particular provisions (for instance, in JTI-MacDonald, Parliament linked "protecting young persons and other from inducements to use tobacco and enhancing public awareness of the health hazards of using tobacco"), it will significantly aid in the argument that the legislation is pressing and substantial. ${ }^{108}$ Given the ability to link plain packaging legislation to a public health RJR-MacDonald Inc. v. Canada (A.G.)” (1997) 24:3 MLJ 665 at 677.

Alberta v Hutterian Brethren of Wilson Colony, 2009 SCC 37, [2009] 2 SCR 567 at para 44 [Hutterian]. RJR-MacDonald, supra note 27 at para 61.

JTI-MacDonald, supra note 27 at para 18. See also Tobacco Act Canada, supra note 3, ss 4(a)-(d).

See also Oakes, supra note 78 at 136. See also JTI-MacDonald, ibid at para 37.

JTI-MacDonald, ibid at para 38. 
objective, it seems unlikely that the legislation would fail at this stage of the Oakes test. It will now be necessary to consider whether plain packaging legislation would pass the proportionality test: is it rationally connected to the objective? Does it impair the right in a minimal fashion? Is it proportionate in effect?

\section{c. Proportionality Test \\ i. Rational Connection}

At this stage of the analysis, the government must establish that the violation of the freedom of expression caused by the adoption of plain packaging legislation is rationally connected to the legislation's objective. ${ }^{109}$ The Supreme Court of Canada has recognized that, although it remains an important step, few cases fail this stage of the analysis. ${ }^{110}$ The threshold for this requirement is quite low; at minimum "it must be possible to argue that the means may help to bring about the objective.”111 Furthermore, the Supreme Court of Canada has recognized that, in situations involving complex social problems, deference may be appropriately granted to Parliament.

In JTI-MacDonald, the Supreme Court of Canada stated that the reduction of tobacco consumption was a complex social problem. Essentially, the Court recognized that an effective solution is not simple, and there will be debate as to what means will effectively combat the problem. As a result of the potential inability to form a consensus on the best means to reduce tobacco consumption, Parliament should be accorded considerable deference. ${ }^{112}$ Thus, the question remains of whether the complete ban on package advertising as a result of plain packaging laws is rationally connected to the public health purpose of combatting tobacco consumption or, quite simply, is it possible to argue that plain packaging of tobacco products may reduce tobacco consumption?

As discussed, the Canadian government has ratified the FCTC. ${ }^{113}$ Pursuant to the guidelines for the implementation of article 11 of the FCTC, participating states, as a means to combat tobacco consumption and discourage the uptake of smoking, are encouraged to adopt plain packaging of tobacco products in their respective jurisdictions. ${ }^{114}$ Furthermore, scientific studies have demonstrated links between a reduction in teen smoking and plain packaging of tobacco products. ${ }^{115}$ One study has also concluded that plain packaging of tobacco products makes cigarettes less satisfying to individual smokers and therefore may

$109 \quad$ Parrish, supra note 103 at 678.

$110 \quad$ JTI-MacDonald, supra note 27 at para 40.

$111 \quad$ Ibid.

$112 \quad$ Ibid at para 41.

113 Supra note 17.

114 Ibid, art 11. For a discussion on how international treaties are currently used by the Supreme Court of Canada in Charter disputes, see Jutta Brunnée \& Stephen J Toope, “A Hesitant Embrace: The Application of International Law by Canadian Courts” (2002) 40 Can YB Int'l L 3; Armand de Mestral \& Evan Fox-Decent "Rethinking the Relationship Between International and Domestic Law" (2008) 53:4 McGill LJ 573; Anne Warner La Forest, "Domestic Application of International Law in Charter Cases: Are We There Yet?” (2004) 37:1 UBC L Rev 157; Gaile McGregor, “The International Covenant on Social, Economic, and Cultural Rights: Will It Get Its Day in Court” (2002) 28 Man LJ 321; Stéphane Beaulac, "Recent Developments on the Role of International Law in Canadian Statutory Interpretation" (2004) 25:1 Stat L Rev 19. 
lead to a reduction in individual consumption. ${ }^{116}$ Given the international recommendation to adopt plain packaging of tobacco products and the scientific studies demonstrating the benefits of such laws, there is clearly a rational connection between the legislation relating to plain packaging of tobacco products and the objective of combating tobacco consumption in Canada. Couple this with the fact that the Supreme Court of Canada has already acknowledged that the government should be granted "considerable deference" in the legislation it chooses to adopt to combat the difficult social problem related to tobacco consumption, it is highly likely that any court would be able to find a rational connection between the legislation (plain packaging) and its stated objective (reduction of tobacco consumption). It now remains to be seen if the legislation can pass the next step in the proportionality test: minimal impairment.

\section{ii. Minimal Impairment}

Once the court has determined that the issue is pressing and substantial, it will then have to determine whether the legislation is minimally impairing. This portion of the test requires that the legislator carefully craft the legislation to ensure that the rights impacted by the impugned law are infringed upon no more than absolutely necessary. ${ }^{117}$ The Supreme Court of Canada has been quick to recognize that it will often be difficult for Parliament to perfectly tailor the legislation. ${ }^{118}$ When determining whether the legislation passes the minimal impairment standard, a court cannot conclude that it fails to meet the standard because the judge is able to conceive of a better way to manage the problem; rather Parliament will only have to demonstrate that "it has tailored the limit to the exigencies of the problem in a reasonable way." 119 As the Supreme Court of Canada stated in Downey, "Parliament is not required to choose the absolutely least intrusive alternative in order to satisfy this branch of the analysis. Rather the issue is 'whether Parliament could reasonably have chosen an alternative means which would have achieved the identified objective as effectively." ${ }^{120}$

As such, similarly to the pressing and substantial branch of the test, a court will grant deference to the legislature to tailor the legislation in the method that the legislature deems the least intrusive. The level of deference granted to Parliament will largely depend on the context; difficult social issues are often granted more deference because precision in the legislation is often elusive. ${ }^{121}$ Since the Supreme Court of Canada has already characterized tobacco control issues as a complex social issue, it is likely that Parliament will be granted more deference in its attempt to tailor legislation that seeks to control or reduce tobacco consumption. While these are the general guidelines for the minimal impairment test, when dealing with freedom of expression interests, the court will also have to consider additional elements related to the content of freedom of expression.

\footnotetext{
116 See Germain, Wakefield \& Durkin, supra note 22.

$117 \quad$ RJR-MacDonald, supra note 27 at para 160.

118 Ibid.

$119 \quad$ Montréal, supra note 65 at para 94.

$120 \quad R v$ Downey, [1992] 2 SCR 10 at 37 [Downey], quoting $R v$ Chaulk, [1990] 3 SCR 1303 at 1341.

121 Ontario v Canadian Pacific Ltd, [1995] 2 SCR 1031; Montréal, supra note 65 at para 94; $R$ v St Onge Lamoureux, 2012 SCC 57, [2012] 3 SCR 187 at para 39; Hutterian, supra note 104 at paras 35, 37.
} 
As discussed, in plain packaging legislation the type of expression being prohibited is not one that falls to the core of the freedom of expression and, given the public health concern of tobacco consumption, a court should grant Parliament deference. Despite this deference, Parliament must still show that the limitation on the freedom of expression can be justified and that its actions are minimally impairing. ${ }^{122}$ This branch of the test may be the hardest for Parliament to justify; in reality, it could be argued, like in JTI-MacDonald, that the same objectives can be met without having to resort to plain packaging. As it stands, Canadian laws mandate that 50 percent of the tobacco packaging must be adorned with warning labels and, it could be argued, that amount is sufficient. For instance, the FCTC states that countries should adopt laws that make warning signs 50 percent of the tobacco product, hence Canada's current laws conform to international legal standard.

That being said, at this stage, the goal is not for the individual judge to find an alternative that is less impairing; rather, the judge must determine whether Parliament has chosen a reasonable alternative that will seek to achieve the identified objective. ${ }^{123}$ Parliament should be able to demonstrate that plain packaging of tobacco products is a reasonable alternative. In RJR-Macdonald, the Court struck down Parliament's tobacco control regulations; in the subsequent case, JTI-Macdonald, tobacco restrictions were upheld. Although the laws were different (the legislation in JTI-Macdonald was a clear attempt by Parliament to implement the Supreme Court of Canada's decision in RJR-Macdonald), the Court did recognize that by the time JTI-Macdonald was litigated, both the domestic and international attitude and education surrounding tobacco smoke had changed. Since RJR-MacDonald, Parliament has benefitted

\begin{abstract}
by increased understanding of the means by which tobacco manufacturers seek to advertise and promote their products and by new scientific insights into the nature of tobacco addiction and its consequences.... tobacco is now irrefutably accepted as highly addictive and as imposing huge personal and social costs. We now know that half of smokers will die of tobacco-related diseases and that the costs to the public health system are enormous. We also know that tobacco addiction is one of the hardest addictions to conquer and that many addicts try to quit time and time again, only to relapse. Moreover, the international context has changed since 1995. Governments around the world are implementing anti-tobacco measures similar to and, in some cases, more restrictive than Canada's. ${ }^{124}$
\end{abstract}

Since 2000, the understanding of the ill effects of tobacco consumption has only increased. ${ }^{125}$ Moreover, clearer understanding of the effects of tobacco advertising indicate that warning labels on tobacco packaging are more effective on a plain package. This method of tobacco control is recommended by the FCTC, and studies have indicated that plain packaging is an effective method in the control of tobacco consumption. ${ }^{126}$ Plain packaging offers benefits that cannot be achieved by increasing the size of warning of labels to take over a larger percentage of the package. Quite simply, it is a tool used to combat tobacco consumption that cannot be easily replicated. Thus, while the tobacco companies may argue

$122 \quad$ JTI-MacDonald, supra note 27 at para 11.

123 Downey, supra note 120.

124 JTI-MacDonald, supra note 27 at paras 9-10.

125 World Health Organization, About the WHO Framework Convention on Tobacco Control (Geneva: World Health Organization, 2013), online: World Health Organization < http://www.who.int/fctc/about/ en/index.html>. 
that there are alternatives, Parliament's standard is simply to show that it has chosen from a list of reasonable measures. If Parliament meets this standard (and given the complexity of the social problem, which suggests greater deference, and prevailing scientific evidence, which shows benefits that are achievable only with plain packaging laws, it should meet the standard), it will still need to meet the final step in the proportionality test: proportionate effect.

\title{
iii. Proportionate Effect
}

The final step in the Oakes test is determining the proportionate effect. Until the Supreme Court of Canada's decision in the Hutterian case, this step was considered irrelevant. As Hogg stated, "[s]o far as I can tell, however, this step has never had any influence on the outcome of any case." ${ }^{\prime 27}$ According to Hogg, this final step is simply a restatement of the first step and is, therefore, redundant. ${ }^{128}$ In 2010, the Supreme Court of Canada explained the significance of this step and answered the criticisms that Hogg had leveled against it. In Hutterian, the Court stated:

\begin{abstract}
It may be questioned how a law which has passed the rigours of the first three stages of the proportionality analysis - pressing goal, rational connection, and minimum impairment - could fail at the final inquiry of proportionality of effects. The answer lies in the fact that the first three stages of Oakes are anchored in an assessment of the law's purpose. Only the fourth branch takes full account of the "severity of the deleterious effects of a measure on individuals or groups."129
\end{abstract}

The Court ruled that the decision in Hutterian ${ }^{130}$ would ultimately be decided on this branch of the Oakes test.

Hogg, supra note 77 at 867. See generally, Sara Weinrib, "The Emergence of the Third Step of the Oakes Test in Alberta v. Hutterian Brethren of the Wilson Colony” (2012) 68:2 UT Fac L Rev 77.

As put by Hogg, ibid:

It is really a restatement of the first step, the requirement that a limiting law pursue an objective that is sufficiently important to justify overriding a Charter right. If a law is sufficiently important to justify overriding a Charter right (first step), and if the law is rationally connected to the objective (second step), and if the law impairs the Charter right no more than is necessary to accomplish the objective (third step), how could its effects then be judged to be too severe? A judgment that the effects of the law were too severe would surely mean that the objective was not sufficiently important to justify limiting a Charter right. If the objective is sufficiently important, and the objective is pursued by the least drastic means, then it must follow that the effects of the law are an acceptable price to pay for the benefit of the law. I conclude, therefore, that an affirmative answer to the first step-sufficiently important objective-will always yield an affirmative answer to the fourth step-proportionate effect. If this is so, then the fourth step has no work to do, and can safely be ignored. Hutterian, supra note 104 at para 76.

130 The Hutterian case dealt with an Albertan law that required photographs to be taken at the time a driver's licence was issued. Prior to 2003, Alberta allowed an exception to the photograph requirement for individuals who objected to the photo based on religious purposes; these religious objectors were given a non-photo licence. In 2003, new government regulations removed the religious objector exemption and required all individuals to have a photo (ibid at para 6). See also Operator Licensing and Vehicle Control Amendment Regulation, Alta Reg 137/2003, s 3. Alberta placed these photographs in a facial recognition data bank that was used in the prevention of identity fraud; the province considered any exemption to the photograph requirement as a potential jeopardy to the integrity of the system. The Hutterian Brethren of Wilson Colony, a religious organization that believed that the second commandment forbids them from having their photograph taken, objected to the removal of the exemption and challenged Alberta's new regulation. The Albertan government did attempt to reach a suitable alternative to the new regulation with the Hutterian Brethren. Two proposed measures that would lessen the impact of the regulations were proposed but were subsequently rejected because they still required a photograph to be taken. 
In Hutterian, the Supreme Court of Canada concluded that there was a violation of the freedom of religion and then turned to examine whether the law could be saved by section 1. After concluding that there was a pressing and substantial reason for the law, that a rational connection existed, and that the law was minimally impairing, the Court turned to analyze the final step of the Oakes test. "In cases such as this, where the demand is that the right be fully respected without compromise, the justification of the law imposing the limit will often turn on whether the deleterious effects are out of proportion to the public good achieved by the infringing measure." 131 The Court, in analyzing this branch of the test, first considered the salutary effects of the provision and then considered the deleterious effects of the provision. The Court then weighed the effects against each other to determine whether it could pass this branch of the Oakes test.

When considering the salutary effects, the Court looked into the benefits that were associated with the law. In Hutterian, the Court examined three benefits: "(1) enhancing the security of the driver's licensing scheme; (2) assisting in roadside safety and identification; and (3) eventually harmonizing Alberta's licensing scheme with those in other jurisdictions." ${ }^{232}$ The Court, at this stage, did take the opportunity to state that the government, when enacting social legislation, does not have to prove that the law produced the benefits that they had intended; the government only has the obligation to adopt measures that "reason and the evidence" indicate will be beneficial. ${ }^{133}$

The Court then moved on to consider the deleterious effects. It is at this stage that the impact of the Charter violation on the affected individuals is examined. ${ }^{134}$ The Court has emphasized that this analysis must be done on a case by case basis and that the seriousness of the limitation will change depending on the facts. ${ }^{135}$ The Court stated that there is no "magic barometer to measure the seriousness of a particular on a religious practice" and that

[t]he bare assertion by a claimant that a particular limit curtails his or her religious practice does not, without more, establish the seriousness of the limit for purposes of the proportionality analysis. Indeed to end the inquiry with such an assertion would cast an impossibly high burden of justification on the state. We must go further and evaluate the degree to which the limit actually impacts on the adherent. ${ }^{136}$

When the Court examined this case, it concluded that while the law on taking photographs was significant to the religion, reasonable alternatives existed (for instance the Brethren could hire drivers) and thus, the impact would be, largely, a financial inconvenience. ${ }^{137}$

After identifying both the benefits and detriments of the Alberta's new regulatory laws, they were then weighed against each other to determine whether the effects were

Hutterian, ibid at para 78.

Ibid at para 79 .

This was done for public benefit. Accordingly, "[i]f legislation designed to further the public good were required to await proof positive that the benefits would in fact be realized, few laws would be passed and the public interest would suffer" (Hutterian, ibid at para 85).

Hutterian, ibid at para 86.

Ibid at para 87. Weinrib argues that Chief Justice McLachlin's judgment regarding the protection of policy formulation "is reminiscent of a line of Canadian cases that call for deference to legislative choice" (Weinrib, supra note 127 at 91).

Hutterian, ibid at paras 89-90.

Ibid at para 99. 
proportionate. In the Hutterian case, the Court acknowledged that the law had an important social goal (the reduction of fraud) that should not be ignored. ${ }^{138}$ Furthermore, when examining the deleterious effects, the Court ruled that although significant financial costs were likely, this was, although not trivial, not a serious violation of the freedom of religion. ${ }^{139}$ As such, the impact of the limit on the freedom of religion was proportionate. ${ }^{140}$

At this stage, any court reviewing the plain packaging legislation would proceed with an analysis similar to the one the Supreme Court of Canada established in the Hutterian case. This means that the court will examine both the salutary and deleterious effects of the legislation and then weigh them against each other to ensure that the impact is proportionate. It is likely that any such analysis would conclude with the finding that the plain packaging legislation is proportionate.

As discussed, the benefits that Parliament seeks to achieve with plain packaging laws are quite straightforward: Parliament is seeking to reduce tobacco consumption. Tobacco consumption is considered to be a public health risk and, as data indicates, it costs the public a significant amount of money and kills a large number of Canadians each year. Laws that reduce tobacco consumption perform an important social service. The potential benefits associated with plain packaging laws are worthy.

On the other hand, the impact of the laws on the freedom of expression cannot be discounted. Plain packaging laws take away the tobacco companies' rights to package their own product as they see fit. Moreover, such laws restrict the advertising capabilities of the companies and can hinder their ability to create an easily recognizable brand. Plain packaging laws affect a commercial right to freedom of expression, and this would not be considered a serious impact on the freedom of expression. ${ }^{141}$ Additionally, alternatives to advertising on packages could remain a viable option for tobacco companies. Thus, the impact would, like in Hutterian, be largely a financial inconvenience. If a court were to balance these two effects, it would likely conclude that given the potential benefits of plain packaging laws versus the deleterious effects, the law is proportional. By passing all branches of the Oakes test, plain packaging legislation would be considered a justifiable limit on the freedom of expression, and the law would be upheld by the court.

\section{CONCLUSION}

In Canada, tobacco companies would likely challenge any attempt by the federal government to pass plain packaging legislation. Under domestic law, such a challenge would centre on the constitutionality of such laws. Given the Supreme Court of Canada's precedent in RJR-Macdonald and JTI-Macdonald, it is unlikely that such laws could be challenged on the basis that the federal government lacked the jurisdiction to pass plain packaging legislation. As the Court stated in JTI-Macdonald, “[r]estrictions on tobacco advertising are a valid exercise of Parliament's criminal law power." "142 This area should be considered

\footnotetext{
$138 \quad$ Ibid at para 101

$139 \quad$ Ibid at para 102

$140 \quad$ Ibid at para 103.

141 See above discussion on Rocket, supra note 68 and Irwin Toy, supra note 51 and accompanying text.
}

$142 \quad$ JTI-MacDonald, supra note 27 at para 20. 
settled law. Instead, the constitutional argument would be based on the Charter, more specifically the freedom of expression guarantee found in section 2(b).

As discussed, the Charter protection of freedom of expression has both a form and content, and "activity is expressive if it attempts to convey meaning." This definition is broad enough to extend freedom of expression protection guarantees to commercial expression. ${ }^{143}$ In JTI-Macdonald, the Supreme Court of Canada ruled that laws which restricted 50 percent of tobacco packaging violated freedom of expression because it interfered with how tobacco companies wished to express themselves. Given the Court's conclusion in JTI-Macdonald, plain packaging laws should also be considered a violation of the freedom of expression. Although it is likely to be found a violation of the right to freedom of expression as discussed, plain packaging laws may be saved under section 1 .

The federal government should be able to make persuasive arguments to justify the infringement of freedom of expression caused by the adoption of plain packaging legislation. Using the section 1 Oakes test, the government will be able to demonstrate that the matter is prescribed by law. Furthermore, given the public health concerns associated with tobacco consumption, the reduction of tobacco consumption would be considered a pressing and substantial issue. The court will then have to consider the proportionality test.

While the minimal impairment branch of the proportionality test may prove more difficult for Parliament to argue, there is reason to believe that plain packaging laws will pass the proportionality section as well. First, as discussed, there is enough evidence, including scientific studies which demonstrate a correlation between plain packaging and the reduction of tobacco consumption, for a court to support a finding that a rational connection between the legislation (plain packaging) and its stated objective (reduction of tobacco consumption) exists. Second, Parliament should be able to demonstrate that it is adopting a law that is minimally impairing. Parliament does not need to demonstrate that the measure chosen is the least impairing, but rather that it is a reasonable alternative. As discussed, plain packaging legislation gives benefits that can only be achieved through plain packaging legislation; this should meet the minimal impairment standard. Finally, Parliament will have to show that there is a proportionate effect. The benefits associated with plain packaging laws are significant, while the effects of the infringement are not as serious. Balancing these factors, the laws will likely be considered proportionate in effect. After an analysis of the Oakes test it is likely that the infringement of the freedom of expression caused by the adoption of plain packaging legislation will be considered a justified limitation on the right.

If enacted, plain packaging legislation would likely be challenged by tobacco companies. However, it seems likely that Parliament would be able to defend such laws. Tobacco consumption is a serious issue with a significant social cost. Internationally, the reduction of tobacco consumption has been an emerging and important issue. More countries are beginning to take action to reduce tobacco consumption in their population through means such as the codification and wide-spread ratification of the FCTC. Pursuant to the FCTC, states are encouraged to adopt plain packaging laws as an effective tool to combat tobacco consumption. Australia has already followed this recommendation, and a recent High Court 
of Australia decision upheld the Commonwealth's rights to enact such legislation. The Australian lead has spurred other countries to begin the debate on plain packaging laws. Canada should also follow suit. New tools that reduce tobacco consumption are necessary, especially given the statistics which show that the reduction of consumption has plateaued. Furthermore, it is likely that such laws can be implemented and justified under domestic law. The Canadian government should consider plain packaging legislation as the next generation of laws in the fight against tobacco consumption and should seriously consider implementing such laws. 